\title{
Assessment of the Physicochemical Quality of Irrigation Water and Soil for Sustainable Irrigated Rice Cultivation: Case of Irrigated Perimeter of M'Bahiakro (Central-East of Côte d'Ivoire)
}

\author{
Ruth Baï1, Innocent K. Kouame1 ${ }^{*}$, Lazare K. Kouassı², Seraphin K. Konan², Hervé A. N’Cho1 \\ ${ }^{1}$ Laboratoire des Sciences de l'Environnement (LSE), UFR Sciences et Gestion de l'Environnement, Université Nangui Abrogoua, \\ Abidjan, Côte d'Ivoire \\ ${ }^{2}$ Laboratoire des Sciences et Technologies de l'Environnement (STE), UFR Environnement, Université Jean Lorougnon Guédé, \\ Daloa, Côte d'Ivoire \\ Email: *kouamein.sge@univ-na.ci, innocent_kouassi@yahoo.fr
}

How to cite this paper: Baï, R., Kouame, I.K., Kouassi, L.K., Konan, S.K. and N'Cho, H.A. (2019) Assessment of the Physicochemical Quality of Irrigation Water and Soil for Sustainable Irrigated Rice Cultivation: Case of Irrigated Perimeter of M'Bahiakro (Central-East of Côte d'Ivoire). Journal of Environmental Protection, 10, 1536-1552.

https://doi.org/10.4236/jep.2019.1011091

Received: October 16, 2019

Accepted: November 17, 2019

Published: November 20, 2019

Copyright $\odot 2019$ by author(s) and Scientific Research Publishing Inc. This work is licensed under the Creative Commons Attribution International License (CC BY 4.0).

http://creativecommons.org/licenses/by/4.0/

\section{(c) (i) Open Access}

\begin{abstract}
This study aims to assess the physico-chemical quality of irrigation water and soil in the irrigated area of M'Bahiakro. Seasonal campaigns to measure in situ the physical parameters $(\mathrm{pH}$, temperature, salinity, electrical conductivity and total dissolved solids) of the N'Zi River were carried out, followed by sampling (water and soil) for chemical analyses. The physico-chemical quality of irrigation water was assessed on the basis of four (4) parameters, namely Dry Residue (SR), Osmotic Pressure ( $\pi$ ), Kelly's Coefficient (KC), Sodium Absorption Rate (SAR) and Wilcox Diagram. In terms of soil quality, the parameters ( $\mathrm{pH}, \mathrm{N}, \mathrm{P}, \mathrm{P}, \mathrm{K}, \mathrm{MO}, \mathrm{CEC}$ and ESP) were determined. Overall, the results show a good physical-chemical quality of the irrigation water and soil. Indeed, the irrigation waters studied show good physico-chemistry and low to medium salinity depending on the seasons of the year. As for the soils, they have a clayey-silt texture, a slightly acidic $\mathrm{pH}$, favourable to rice cultivation and a good organic matter content, which best maintains an active microbial life. In addition, the major elements (nitrogen, phosphorus and potassium) present in irrigation water and soils could be enough to optimize the yield of rice cultivation. These results then lead to the conclusion that the irrigation water from the N'Zi River and the soils of the irrigated perimeter of M'Bahiakro are naturally suitable for agricultural use, particularly for rice cultivation. As a result, an additional supply of fertilizer (NPK) would not necessarily be necessary during the exploitation phase of the rice area.
\end{abstract}




\section{Keywords}

Irrigation, Sustainable Rice Cultivation, Water and Soil Management, M'Bahiakro

\section{Introduction}

Irrigated agriculture is of particular importance for the economic development of developing countries. It represents a strategy to reduce food insecurity as irrigated crops produce about $40 \%$ of total agricultural production and their yields are generally twice as high as those of rainfed crops [1]. In addition, irregular rainfall patterns and subsequent crop failures make irrigation systems an efficient production tool [2] [3] [4]. In Côte d'Ivoire, where national rice production covers only about $50 \%$ of the needs of the Ivorian population [5], the development of irrigation systems has been identified by the State as the channel through which the country could rapidly increase its domestic production, reduce its imports and ease the population's demand for rice. Thus, the Ivorian State, with the support of donors, has built several dams in different localities of the country such as M'Bahiakro (Centraleast of Côte d'Ivoire) to support the development of irrigation systems and the management of rice production in the dry season [6]. However, while the development of rice areas by irrigation systems leads to a substantial improvement in yields, in some cases it leads to a deterioration in water and soil quality [7] due sometimes to the abusive use of inputs by producers. Therefore, a qualitative and quantitative control of agricultural fertilizers is necessary in order to minimize the loss of inputs likely to lead to soil and water degradation in the vicinity. Thus, knowledge of the initial quality of irrigation water and soils in the rice growing area becomes essential in order to know the nutrients already present in water and soil for irrigation. Preliminary studies have been carried out by authors in this regard [6]. However, these studies remain summary and do not take soil quality into account. It is therefore to know the initial quality of the water of the river used for irrigation as well as the initial soil quality of the M'Bahiakro rice area that the present study was initiated. It aims to assess the physical and chemical quality of irrigation water and soil fertility in the irrigated area of M'Bahiakro for sustainable rice cultivation.

\section{Site and Methods}

\subsection{Presentation of the Study Area}

The study site is an irrigated perimeter of $450 \mathrm{ha}$, located $6 \mathrm{~km}$ north-east of the town of M'Bahiakro (Central east of Côte d'Ivoire) (Figure 1). Located between longitudes 335,000 and $365,000 \mathrm{~W}$ and latitudes 815,000 and $842,500 \mathrm{~N}$, the M'Bahiakro rice area is home to Côte d'Ivoire's first inflatable dam. The study area is influenced by the equatorial climate of attenuated transition with four 
distinct seasons: a large rainy season from March to June followed by a small dry season between July and August. The small rainy season occurs in September and ends at the beginning of November. The months of November, December, January and February are the main dry season. Monthly rainfall varies between 0 and $160 \mathrm{~mm}$ with an annual rainfall of $1000 \mathrm{~mm}$ [6]. The average annual temperature ranges from $25.6^{\circ} \mathrm{C}$ to $29.1^{\circ} \mathrm{C}$. The main activity of the inhabitants of the area is agriculture.

\subsection{Water Sampling}

Water samples were collected from three (03) monitoring stations (E1: upstream, E2: dam and E3: downstream) (Figure 1). Parameters such as $\mathrm{pH}$, temperature, electrical conductivity and water salinity were measured in situ using a HANNA 9828 multi-parameter probe. Water samples were also collected in labelled bottles for analysis in the laboratory. These bottles were washed and rinsed several times with deionized water and sample before collection. The samples were transported to the laboratory in a cooler and stored at $4^{\circ} \mathrm{C}$ before analysis. Sampling was carried out according to the hydrological seasons. Thus, field observations were made in July 2018 (short dry season), September 2018 (short rainy season), December 2018 (long dry season) and June 2019 (long rainy season). Samples were collected, transported and stored according to the protocol defined by AFNOR. A total of 12 water samples were analyzed.

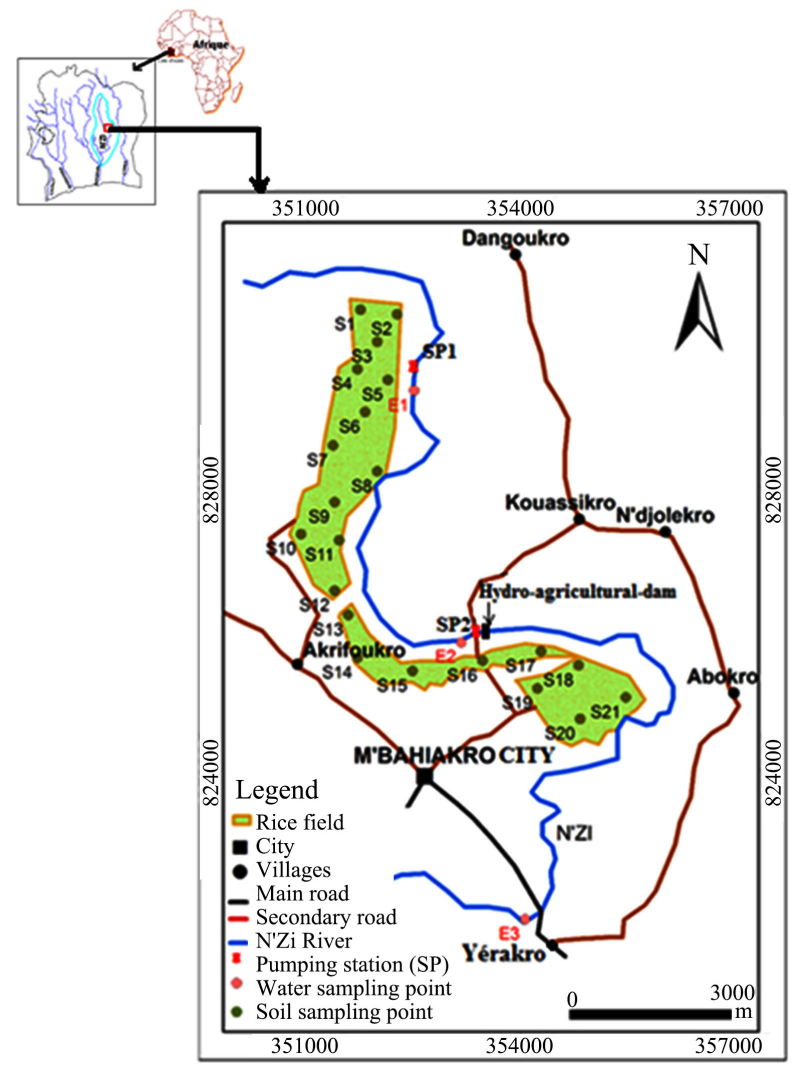

Figure 1. Location of the irrigated perimeter of M'Bahiakro. 


\subsection{Soil Sampling}

Twenty-one observation sites (S1 to S21) representative of the study area were identified from a map (Figure 1). The exact location of the observation sites was done by GPS. Soil sampling was carried out using a manual auger at the level of the first 30 centimeters of soil. Soil samples were collected for laboratory analysis. The lack of sampling during the rainy season (September 2018) is due to the flooding of rainwater in the study area during that season.

\subsection{Physico-Chemical Analyses}

\subsubsection{Water}

The physico-chemical analyses of the water samples were carried out according to the experimental protocol defined by AFNOR, recorded in Table 1. In the laboratory, the water samples were acidified by adding a few drops of sulphuric acid $\left(\mathrm{H}_{2} \mathrm{SO}_{4}\right)$. For the reliability of the analytical results, the ion balance method was applied and a minus 5\% error was accepted.

\subsubsection{Soil}

The analysis of mineral elements in soil samples is preceded by extraction and preparation of these elements. Soil grain size was determined by the dry sieving method. Table 2 presents the different methods of analysis of soil samples.

Table 1. Methods of analysis of chemical parameters of water samples.

\begin{tabular}{ccc}
\hline Parameters & Methods & Standards \\
\hline $\mathrm{Ca}^{2+}$ et $\mathrm{Mg}^{2+}$ & Complexometry with EDTA & NFT90-003 \\
$\mathrm{Cl}^{-}$ & Mohr method & NFT 90-014 \\
$\mathrm{HCO}_{3}^{-}$ & Titrimetric method & NFT 90-036 \\
$\mathrm{NO}_{3}^{-}$ & NFT 90-013 \\
$\mathrm{NO}_{2}^{-}$ & Colorimetry: Spectrophotometry HACH LANGE DR 6000 & NFT 90-012 \\
$\mathrm{SO}_{4}^{-}$ & NFT 90-040 \\
$\mathrm{PO}_{4}^{3-}$ & Indophenol blue spectrophotometric & NFT 90-023 \\
$\mathrm{Na}^{+}, \mathrm{K}^{+}$ & Flame atomic absorption spectrophotometer (SAAF) type VARIAN & NFT90-020 \\
$\mathrm{NH}_{4}^{+}$ & NFT 90-015 \\
\hline
\end{tabular}

Table 2. Methods of analysis of chemical parameters of soil samples.

\begin{tabular}{ccc}
\hline Parameters & Methods & Standards \\
\hline Soil organic matter (MOS) & Walkey and Black method & NF ISO 10694 \\
Total Nitrogen (NT) & Kjeldahl digestion method & NF ISO 13878 \\
$\mathrm{pH}$ & Electrometric method & NF ISO 10390 \\
$\mathrm{CEC}$ & Metson method & NF X31-130 \\
Assimilable Phosphorus & OLSEN method & NF ISO 11263 \\
Exchangeable bases $\left(\mathrm{Ca}^{2+}, \mathrm{K}^{+}, \mathrm{Mg}^{2+}, \mathrm{Na}^{+}\right)$ & Fluoro-nitro-perchloric method & NF X 31-108 \\
\hline
\end{tabular}




\subsection{Data Processing Method}

\subsubsection{Assessment of the Suitability of Water for Irrigation}

For the assessment of the physico-chemical quality of the water, four (4) parameters, namely the Dry Residue ( $\mathrm{RS}=0.7 \times \mathrm{CE}(\mu \mathrm{S} / \mathrm{cm}))$, osmotic pressure $(\pi=$ $0.00036 \times \mathrm{CE})$, Kelly's coefficient $\left(\mathrm{RK}=\mathrm{Na}^{+} /\left(\mathrm{Ca}^{2+}+\mathrm{Mg}^{2+}\right)\right.$ ), Sodium Absorption Rate $\left(\mathrm{SAR}=\mathrm{Na}^{+} / \sqrt{\left(\mathrm{Ca}^{2+}+\mathrm{Mg}^{2+}\right)}\right)$ and Wilcox diagram were retained. These methods describe the alkalizing power of water and make it possible to assess the potential risk of soil salinization.

\subsubsection{Assessment of the Physico-Chemical Quality of Soils}

Soil quality was assessed by analysing the physical (texture, hydraulic conductivity) and chemical parameters of the soil (EC, nitrogen, potassium, phosphorus, CEC and the exchangeable sodium content $\left(\mathrm{ESP}=\left(\mathrm{Na}^{+} \times 100\right) /\left(\mathrm{CCa}^{2+}+\mathrm{Mg}^{2+}+\right.\right.$ $\left.\mathrm{K}^{+}+\mathrm{Na}^{+}\right)$).

\subsubsection{Statistical Processing of Data}

Descriptive statistical analysis was performed to calculate the mean, standard deviation and total range of the variable (maximum, minimum).

\section{Results and Discussion}

\subsection{Water Quality of the N'Zi River}

\subsubsection{Characterization of the Waters of the N'Zi River}

The results of the analyses of the physico-chemical parameters of irrigation water are recorded in Table 3. The analysis of this table shows average values of temperatures between $25^{\circ} \mathrm{C}$ to $28^{\circ} \mathrm{C}$ and $\mathrm{pH}$, slightly acidic $(\mathrm{pH}=5)$ in the rainy season and close to neutrality $(\mathrm{pH}=7)$ in the dry season. These temperatures within the normal range of seasonal variations in atmospheric temperatures in Ivory Coast [8] are favourable to the development of rice cultivation. Indeed, in rice cultivation, the subsequent development of plants below $25^{\circ} \mathrm{C}$ induces the sterility of spikelets with great sensitivity during the swelling stage of panicles in the seed [9]. Thus, temperature remains the most important factor for rice quality, especially at the grain filling stage [10]. The decrease in $\mathrm{pH}$ in the rainy season could be due to the presence of high organic matter levels and the increase in the dry period, when evaporation is high [11]. However, in term of $\mathrm{pH}$, the water from the N'Zi River is suitable for plant growth and therefore for rice production according to FAO irrigation standards [12]. The waters studied have an average electrical conductivity (EC) $(<600 \mu \mathrm{s} / \mathrm{cm})$ lower than recommended $(3000 \mu \mathrm{s} / \mathrm{cm})$ [13]. They are also more mineralized in the dry season with a maximum value of $546 \mu \mathrm{s} / \mathrm{cm}$ compared to $142.1 \mu \mathrm{s} / \mathrm{cm}$ recorded in the rainy season. Indeed, during the dry season, the rise in temperature favours the evaporation of surface water, which often results in a fairly high concentration of ions in the sampled waters, while the dilution of the concentrations of ions observed during the rainy season. Since the average EC values are below the WHO recommended value, the waters of the N'Zi River remain free of irrigation 
Table 3. Results of physico-chemical parameters of irrigation water at M'Bahiakro.

\begin{tabular}{|c|c|c|c|c|c|c|c|c|c|c|c|c|c|c|c|c|c|}
\hline & & July & 2018 & & & Septemb & er 2018 & & & Decemb & er 2018 & & & June & 2019 & & \\
\hline $\begin{array}{c}\text { PHYSICAL } \\
\text { PARAMETERS }\end{array}$ & Mini & Maxi & Mean & SD & Min & $\operatorname{Max}$ & Mean & SD & Min & $\operatorname{Max}$ & Mean & SD & Min & $\operatorname{Max}$ & Mean & SD & Standards \\
\hline $\mathrm{pH}$ & 6.50 & 7.48 & 7.07 & 0.51 & 4.90 & 5.65 & 5.38 & 0.41 & 6.31 & 7.17 & 6.74 & 0.43 & 6.74 & 6.86 & 6.82 & 0.07 & $6.5-8.4$ \\
\hline $\mathrm{T}^{\circ} \mathrm{C}$ & 25.26 & 26.10 & 25.66 & 0.42 & 26.80 & 28.06 & 27.62 & 0.65 & 26.80 & 27.80 & 27.46 & 0.51 & 25.00 & 26.00 & 25.60 & 1.04 & 35 \\
\hline Sal (\%o) & 0.05 & 0.29 & 0.13 & 0.14 & 0.00 & 0.01 & 0.00 & 0.01 & 2.40 & 5.20 & 3.33 & 1.62 & 0.01 & 0.02 & 0.01 & 0.00 & 3.5 \\
\hline $\mathrm{EC}(\mu \mathrm{s} / \mathrm{cm})$ & 114.00 & 594.00 & 278.00 & 273.70 & 80.00 & 170.00 & 123.30 & 45.09 & 397.00 & 839.00 & 546.30 & 253.50 & 129.20 & 155.60 & 142.10 & 13.21 & 3000 \\
\hline TDS (mg/L) & 57.00 & 297.00 & 139.00 & 136.80 & 40.00 & 80.00 & 6.67 & 23.09 & 197.00 & 427.00 & 274.00 & 132.50 & 134.00 & 155.00 & 146.00 & 10.81 & 2000 \\
\hline $\begin{array}{c}\text { CHEMICAL } \\
\text { PARAMETERS }\end{array}$ & Min & $\operatorname{Max}$ & Mean & SD & Min & $\operatorname{Max}$ & Mean & SD & Min & $\operatorname{Max}$ & Mean & SD & Min & $\operatorname{Max}$ & Mean & SD & Standards \\
\hline $\mathrm{SO}_{4}^{2-} \quad(\mathrm{mg} / \mathrm{L})$ & 16.40 & 6.20 & 31.37 & 24.98 & 6.00 & 10.10 & 8.03 & 2.05 & 13.00 & 19.00 & 16.50 & 3.12 & 0.65 & 1.25 & 0.87 & 3.12 & 250 \\
\hline $\mathrm{NO}_{2}^{-} \quad(\mathrm{mg} / \mathrm{L})$ & 0.00 & 0.01 & 0.01 & 0.00 & 0.00 & 0.00 & 0.00 & 0.00 & 0.20 & 0.21 & 0.20 & 0.01 & 0.00 & 0.00 & 0.00 & 0.01 & 3 \\
\hline $\mathrm{NH}_{4}^{+} \quad(\mathrm{mg} / \mathrm{L})$ & 0.07 & 0.08 & 0.08 & 0.01 & 0.01 & 0.03 & 0.02 & 0.01 & 1.01 & 1.15 & 1.07 & 0.07 & 0.81 & 2.60 & 1.57 & 0.07 & 0.5 \\
\hline $\mathrm{PO}_{4}^{3-} \quad(\mathrm{mg} / \mathrm{L})$ & 0.03 & 0.06 & 0.05 & 0.02 & 0.22 & 0.35 & 0.31 & 0.08 & 0.43 & 0.46 & 0.44 & 0.02 & 0.11 & 0.16 & 0.13 & 0.02 & 0.2 \\
\hline $\mathrm{Ca}^{2+}(\mathrm{mg} / \mathrm{L})$ & 2.50 & 3.00 & 2.70 & 0.27 & 6.50 & 8.00 & 7.17 & 0.76 & 13.90 & 15.80 & 14.60 & 1.04 & 15.40 & 17.90 & 16.80 & 1.04 & 120 \\
\hline $\mathrm{K}^{+}(\mathrm{mg} / \mathrm{L})$ & 7.20 & 16.40 & 13.10 & 5.09 & 0.84 & 1.40 & 1.12 & 0.28 & 2.90 & 4.20 & 3.70 & 0.70 & 5.00 & 5.80 & 5.50 & 0.70 & 5 \\
\hline $\mathrm{Mg}^{2+}(\mathrm{mg} / \mathrm{L})$ & 1.40 & 1.50 & 1.47 & 0.05 & 0.00 & 0.00 & 0.00 & 0.00 & 0.43 & 1.23 & 0.87 & 0.25 & 0.26 & 2.58 & 1.22 & 0.25 & 25 \\
\hline $\mathrm{Cl}^{-}(\mathrm{mg} / \mathrm{L})$ & 8.40 & 30.50 & 15.90 & 12.62 & 3.00 & 5.00 & 4.00 & 1.00 & 8.90 & 18.00 & 11.97 & 5.23 & 2.90 & 4.00 & 3.40 & 5.23 & 140 \\
\hline $\mathrm{Na}^{+}(\mathrm{mg} / \mathrm{L})$ & 2.20 & 9.80 & 4.77 & 4.36 & 1.66 & 2.76 & 2.21 & 0.55 & 2.40 & 8.00 & 4.30 & 3.21 & 0.53 & 0.60 & 0.56 & 3.21 & 30 \\
\hline
\end{tabular}

TDS: Total Dissolved Solid; Mini: Minimum; Maxi: Maximum; Standard-Deviation: SD.

concerns. As for the average values of TDS (139 to $274 \mathrm{mg} / \mathrm{L}$ ) and salinity $(0.133 \%$ to $3.33 \%$ ) , obtained, they followed the similar trend of the EC and showed a similar variation during the study, i.e. high in the dry season and low in the rainy season. Based on irrigation standards [13], these average values of TDS $(>2000 \mathrm{mg} / \mathrm{L})$, salinity $(>3.5 \%$ o $)$ and EC $(>3000 \mu \mathrm{s} / \mathrm{cm})$, confirm that the waters of the N'Zi River are suitable for irrigation.

Chemical analysis of water parameters shows average magnesium levels lower than those of calcium throughout the study period (2018 to 2019). This could be explained by the high solubility of magnesium in water, which is about five times higher than that of calcium [14]. However, the average calcium and magnesium levels in the waters of the N'Zi River remain below irrigation standards [15] and are therefore conducive to irrigation.

As for the average levels of sodium, chloride and sulphate obtained in irrigation water, they also remain below the maximum concentrations recommended by [15] and reveal that the waters of the N'Zi River do not present any danger related to irrigation. During the study, ammonia was detected in the N'Zi River at moderate concentrations $(1.077 \mathrm{mg} / \mathrm{L}$ in December 2018 and $1.57 \mathrm{mg} / \mathrm{L}$ in June 2019), generally above those recommended $(0.5 \mathrm{mg} / \mathrm{L})$ by irrigation standards [15]. This reflects contamination of the waters of the N'Zi River by ammonia, the origin of which could be attributed to a biodegradation process of organic matter [16] [17] and to the leaching process of the agricultural land sur- 
rounding the dam [18]. These high concentrations of ammonia in water can lead to excessive algal growth that can harm aquatic life [19], while altering the quality of irrigation water [20].

Similarly, the high concentrations of phosphorus $(<0.2 \mathrm{mg} / \mathrm{L}$ in 2018) and potassium (in July 2018 at $13.07 \mathrm{mg} / \mathrm{L}$ and June 2019 at $5.5 \mathrm{mg} / \mathrm{L}$ ) observed in the N'Zi River could be attributed to natural alteration of submerged soil and rocks, the atmosphere (wind, rain), shoreline vegetation and bank erosion [19] [20] [21] [22] especially when river flow is low. In addition, it should be noted that the dam's retention is located in a watershed with a medium vegetation cover and which, following its erosion by rainfall, mobilizes huge quantities of suspended matter and nutrients towards the reservoir lake [20]. However, according to our observations, the N'Zi River at M'Bahiakro is free of algal blooms, despite phosphorus concentrations above $0.1 \mathrm{mg} / \mathrm{L}$ and ammonia. This situation usually leads to rapid development of aquatic plants (algae), probably due to the high flow rate of the river, which would prevent the proliferation of algae. Effect, since river systems generally flow, there does not appear to be any cumulative enrichment of specific parameters from one season to the next [2]. Thus, these high levels of phosphorus, potassium and ammonia do not constitute a danger to rice irrigation. On the other hand, the low average concentrations of nitrate $(<30 \mathrm{mg} / \mathrm{L})$ and nitrite $(<3 \mathrm{mg} / \mathrm{L})$ obtained during the entire study period could be explained by the fact that no agricultural activity near the N'Zi River was carried out. Indeed, some authors ([2] [23] [24]) attribute high nitrate concentrations in water to the importance of agricultural activities and the application of nitrogen fertilizers. In addition, these concentrations of nitrites and nitrates in the waters of the N'Zi River at M'Bahiakro are acceptable for crop irrigation.

\subsubsection{Water Suitability of the N'Zi River for Irrigation}

The suitability of water for irrigation use is estimated from the sodium absorption ratio (SAR), Kelly's coefficient (KC), Dry Residue (RS), osmotic pressure $(\pi)$ (Table 4 ) and Wilcox diagram (Figure 2). SAR is an expression of the ability of sodium ions to exchange with calcium and magnesium ions in the soil, which measures the suitability of water for irrigation use with respect to sodium risk ([25] [26] [27]). In this study, the average SAR concentrations obtained in irrigation water are less than $10 \mathrm{meq} / \mathrm{l}$ for all seasons. Thus, these irrigation waters fall into the category of "water of excellent quality, with low risk of alkalinization". These SAR results for the N'Zi River corroborate those obtained by [28]. In addition, by associating the EC with the SAR, the waters of the N'Zi River are divided into two classes: $\mathrm{C} 1 \mathrm{~S} 1$ and $\mathrm{C} 2 \mathrm{~S} 1$ corresponding respectively to water of low and medium salinity. Class C1S1 water obtained in the rainy season is safe for most crops and can be used without particular control for irrigation while class C1S2 water obtained in the dry season is suitable for plants with a low salt tolerance. Thus, during the dry season, it would be necessary to ensure that leaching into low-permeability soils is difficult for any permanent use of class C1S2 water, in the absence or malfunction of a drainage system [29]. 
Table 4. Results of irrigation water quality parameters.

\begin{tabular}{|c|c|c|c|c|c|c|c|c|c|c|c|c|c|c|c|c|}
\hline & \multicolumn{4}{|c|}{ July 2018} & \multicolumn{4}{|c|}{ September 2018} & \multicolumn{4}{|c|}{ December 2018} & \multicolumn{4}{|c|}{ June 2019} \\
\hline & RS & $\pi$ & SAR & $\mathrm{RK}$ & RS & $\pi$ & SAR & RK & RS & $\pi$ & SAR & $\mathrm{RK}$ & RS & $\pi$ & SAR & RK \\
\hline Min & 79.80 & 0.04 & 0.19 & 0.38 & 56.00 & 0.03 & 0.11 & 0.18 & 277. 90 & 0.14 & 0.11 & 0.12 & 90.44 & 0.05 & 0.02 & 0.02 \\
\hline $\operatorname{Max}$ & 415.80 & 0.21 & 0.82 & 1.56 & 119.00 & 0.06 & 0.20 & 0.48 & 587.30 & 0.30 & 0.87 & 1.00 & 108.90 & 0.06 & 0.02 & 0.03 \\
\hline Moy & 194.60 & 0.10 & 0.40 & 0.79 & 86.33 & 0.04 & 0.16 & 0.32 & 382.40 & 0.19 & 0.46 & 0.53 & 99.46 & 0.05 & 0.02 & 0.03 \\
\hline SD & 191.61 & 0.09 & 0.35 & 0.67 & 31.56 & 0.02 & 0.04 & 0.15 & 177.40 & 0.09 & 0.38 & 0.44 & 9.24 & 0.01 & 0.00 & 0.00 \\
\hline
\end{tabular}

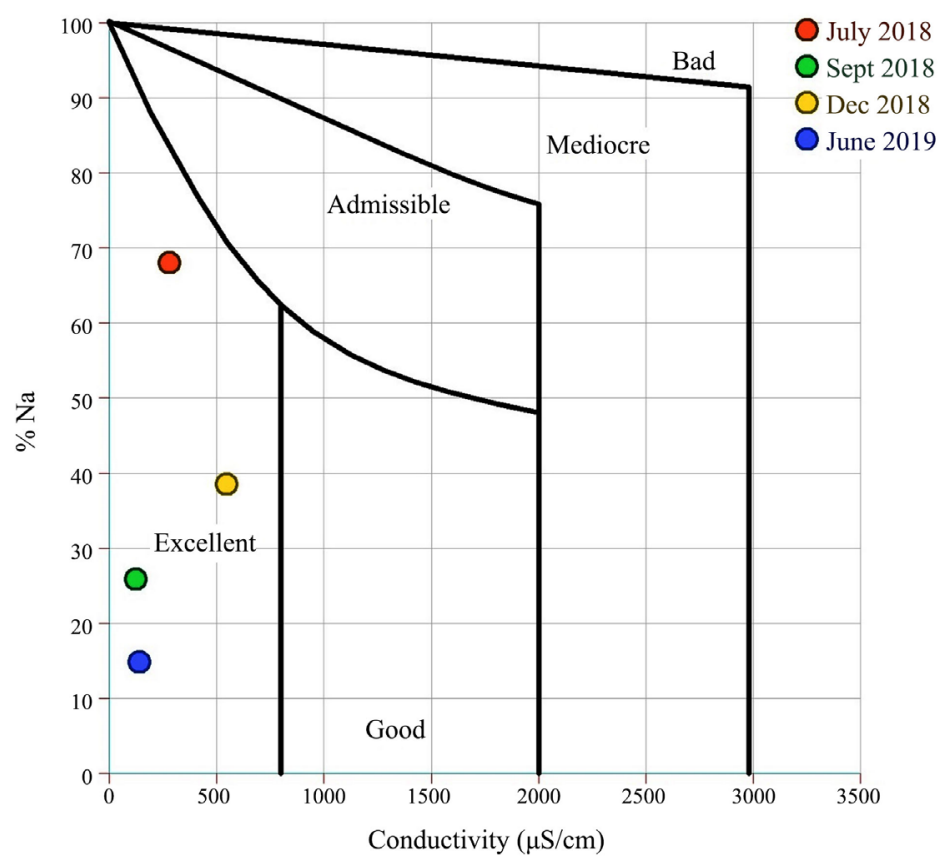

Figure 2. Classification of irrigation water at M'Bahiakro based on Wilcox Diagram [34].

In addition, one of the consequences of salinization is also the modification of the osmotic potential of the soil solution, when the salt content increases. Indeed, the more salty the soil solution is, the higher the osmotic pressure is and the more difficult it is for the roots to extract water from the soil reserve. Thus, it is all the easier for the soil solution to be at a lower osmotic pressure [30] for the proper development of the plant. In addition, at the N'Zi River, the average osmotic pressure values $(\pi)$ obtained are less than 0.27 atm (threshold value) and attest that irrigation water is safe for rice crop development.

Another limiting parameter for determining whether water is suitable for irrigation is Dry Residue (RS). Indeed, Dry Residue (RS) is an indicator of overall mineralization or electrical conductivity (EC). The more mineralized a water is, the higher its Dry Residue is and the less "incompatible" it is with irrigation. In other words, water with a low or medium dry residue content could be used for irrigation on almost all types of soil, while water with a high dry residue content represents a considerable risk in some fine-textured soils, particularly in soils with low leaching. The average dry residue (RS) values obtained (RS $<525$ 
$\mathrm{mg} / \mathrm{L}$ ) during this study indicate that the sampled waters of the N'Zi River are good for irrigation for almost all types of soil and regardless of seasonal variations.

The Kelly coefficient (KC), on the other hand, is an important parameter that measures the ease of use of irrigation water [31]. Waters with a $\mathrm{KC}<1$ are classified as "suitable" for crop irrigation, while waters with a $\mathrm{KC}>1$ are considered "unsuitable" [32] [33]. Thus, the KC values calculated at the level of water samples taken from the N'Zi River are all below 1, for all seasons, indicating that the waters of the N'Zi River are "suitable" for crop irrigation. The KC obtained in the waters of the N'Zi river, of M'Bahiakro, are in accordance with those obtained by the authors [29] in the groundwater of the Agboville department (South-East Côte d'Ivoire) for agricultural use.

The Wilcox diagram [34] which expresses the percentage of sodium $(\% \mathrm{Na})$ in relation to electrical conductivity (EC) was also used for the classification of irrigation water quality. Figure 2 shows that the sampled waters of the N'Zi River are all in the "excellent" category regardless of seasonal variations. Therefore, the waters of the N'Zi River are "suitable" for irrigation use. It can therefore be assumed that water from the N'Zi River can be used for irrigation without prior soil management practices before the development of the plots in the irrigated area.

\subsection{Soil Quality of the Rice Area}

\subsubsection{Physical Characterization of Soils in the Rice Area}

The granulometric results of the soils studied show that more than $70 \%$ of the soil samples have a clayey-loam texture, favourable for rice cultivation. The average hydraulic conductivity values obtained at ground level in the study area range from $10^{-4}$ to $10^{-3} \mathrm{~m} / \mathrm{s}$. However, these average hydraulic conductivity values indicate a high infiltration (6\%) of the water into the unsaturated zone [35]. This is not suitable for rice cultivation, because in reality, soils suitable for rice cultivation are soils with very low permeability and high-water retention capacity so as to avoid water loss through underground drainage [36].

\subsubsection{Chemical Characterization of Soils in the Rice Area}

Table 5 provides information on the results of physico-chemical analyses of soil samples. The average $\mathrm{pH}$ values of the soils studied indicate that they are slightly acidic ( $\mathrm{pH}=6.38$ ), thus favourable for rice cultivation [37]. Indeed, the ideal $\mathrm{pH}$ varies according to the nature of the soil and the crop, however, as a general rule, a slightly acid pH is sought which is then favourable to assimilation [38].

The average assimilable phosphorus values (532.3 ppm) obtained are above the critical threshold of $179 \mathrm{ppm}$. This high level of available phosphorus may be due to the fact that soils, in general, contain a large amount of phosphorus, which may exceed 15 to 1550 times the need for plants [39]. In addition, excess phosphorus in the soil could result from the high mineralization of plant residues as a result of microbial activity. In addition, this excess phosphorus $(<175$ 
Table 5. Results of physico-chemical parameters of soil samples.

\begin{tabular}{|c|c|c|c|c|c|}
\hline \multirow[b]{2}{*}{$\begin{array}{l}\text { Physico-chemical } \\
\text { parameters }\end{array}$} & \multicolumn{4}{|c|}{ Uncultivated plots (fallow land) } & \multirow[t]{2}{*}{ Standards } \\
\hline & Mini & Maxi & Mean & SD & \\
\hline $\mathrm{pH}(\mathrm{Cmol} / \mathrm{kg})$ & 5.42 & 7.02 & 6.38 & 0.46 & $5.5 \leq \mathrm{pH} \leq 7.5$ \\
\hline $\mathrm{Ca}^{2+}(\mathrm{Cmol} / \mathrm{kg})$ & 1.12 & 4.64 & 2.24 & 1,17 & $5-8$ \\
\hline $\mathrm{Mg}^{2+}(\mathrm{Cmol} / \mathrm{kg})$ & 3.16 & 10.53 & 5.60 & 2.78 & $1.5-3.0$ \\
\hline $\mathrm{Na}^{+}(\mathrm{Cmol} / \mathrm{kg})$ & 0.1 & 1.6 & 0.50 & 0.45 & $0.3-0.7$ \\
\hline $\mathrm{K}^{+}(\mathrm{Cmol} / \mathrm{kg})$ & 0.78 & 1.68 & 1.17 & 0.28 & $0.15-0.25$ \\
\hline $\mathrm{CEC}(\mathrm{Cmol} / \mathrm{kg})$ & 9.23 & 18.26 & 12.93 & 3.44 & $10 \leq \mathrm{CEC} \leq 25$ \\
\hline OM (\%) & 3.89 & 5.34 & 4.63 & 0.48 & $3.6-6.5$ \\
\hline TOC (\%) & 2.26 & 3.10 & 2.71 & 0.29 & $1.26-2.5$ \\
\hline Phos A (ppm) & 409.00 & 721.00 & 532.30 & 97.48 & $134-179$ \\
\hline $\mathrm{N}(\%)$ & 0.05 & 0.08 & 0.07 & 0.01 & $0.2-0.25$ \\
\hline
\end{tabular}

TOC: Total Organic Carbon; Phos A: Assimilable Phosphorus.

$\mathrm{mg} / \mathrm{kg}$ ) observed in soils without irrigated perimeter cultivation are not inherently toxic to terrestrial and aquatic fauna and flora, quite the contrary, they may allow a good yield of rice cultivation by increasing resistance to lodging and disease, thus giving a less stained, beautiful looking paddy [40]. Potential sources of phosphorus pollution in surface waters are due to anthropogenic activities such as discharges of plant effluent, sewage, and especially agricultural input discharges [41]. The high initial phosphorus content of the soil at the M'Bahiakro irrigated area is enough to cover rice production needs. Therefore, no additional input would be required at the time of exploitation of the said perimeter, as it could present a latent danger for the contamination of the waters of the N'Zi River.

The same is true for potassium, where the average levels $(1.17 \mathrm{Cmol} / \mathrm{kg})$ are higher than the standard range $(0.15$ to $0.25 \mathrm{Cmol} / \mathrm{kg})$. These high potassium levels can be reported either to the nature of the parent rock, rich in silicate minerals (potassium feldspar, micas, clays) or soil humus, the content and type of which determine the potassium potential [42]. Excess potassium in the soil is essential for the proper development of the plant, as potassium remains among the three basic nutrients (NPK), the element most absorbed by plants in higher amounts [43]. Some authors [44] [45] have reported that frequent luxury consumption of potassium has never resulted in measurable toxicity. As a result, the high potassium levels observed in the irrigated perimeter of M'Bahiakro indicate that the soils have good potassium fertility. As a result, rice cultivation at the level of the said area can be carried out without the use of potassium fertilizers, or even without interruption for years, and sometimes even decades. However, these excessive potassium levels can lead to antagonisms that lead to other types of deficiencies, such as magnesium or calcium deficiency, even if 
they are present in sufficient quantities in the soil [46] [47]. This seems quite justified in the case of calcium, where soil levels in the irrigated area are very low $(2.24<8 \mathrm{Cmol} / \mathrm{kg})$. On the other hand, magnesium, often considered as a semi-oligo-element, has a very high content $(5.6>3 \mathrm{Cmol} / \mathrm{kg})$ suitable for rice cultivation.

Unlike very high levels of phosphorus and potassium, the average nitrogen content in soils $(0.07 \%)$ is much lower than the range of normative values $(0.2 \%$ - 25\%). This result is similar to the study of fallow soils conducted in Ghana where nitrogen levels ranged from $0.033 \%$ to $0.303 \%$ [48]. However, it should be noted that organic nitrogen is not directly available to plants; it must first be mineralized. Thus, most plants only use nitrogen combined with other atoms (such as ammoniums, nitrates, etc.). However, the study of the dynamics of this mineralization has shown that after a phase of inactivity in the dry season, microbial phenomena are stimulated by the first rains and result in significant mineralization flows [49] [50]. This reflects a low amount of nitrogen in the dry season compared to the rainy season when the content is higher. This average nitrogen content obtained at the level of the irrigated perimeter of M'Bahiakro could be explained by this phenomenon of mineralization in the dry season, given that soil sampling took place during the main dry season (December 2018). In addition, some studies have shown that nitrogen, the most vital nutrient for rice growth, is present in the soil, but often in insufficient quantities [51], probably because of soil organisms that use any nitrogen to break down carbon sources. However, nitrogen deficiency is considered to be the main cause of agricultural yield losses [52]. Thus, in view of the low average nitrogen content obtained during this study, it would be necessary for an adequate supplement of nitrogen fertilizer to be applied to the soils of the irrigated area during the exploitation phase to improve the yield of rice cultivation.

The soils studied have an average organic matter (OM) content $(4.63 \%)$ within the range $(3.5 \%-6.5 \%)$ of the normative values. This good organic matter content could be explained by the long period of set-aside of the plots in the irrigated area, which favoured significant organic inputs. The presence of organic matter in the soils of the irrigated area is an indicator of good soil fertility and good rice crop yield. Indeed, organic matter plays a physical role in the soil for cohesion, structure, porosity, water retention or storage, etc. [53]. It also plays a biological role in stimulating biological activity (earthworms, microbial biomass). Finally, it plays a chemical role in plant nutrition through degradation, mineralization, etc. [54]. This result of organic matter in our study area is contrary to other studies that have shown that the vast majority of soils in West Africa in general are very poor in organic matter [55].

The soils studied showed no limitations in terms of Total Organic Carbon (TOC) content, quite the contrary, the levels obtained (2.71\%) are above the normative value range $(1.26 \%-2.5 \%)$. This reflects a much more favourable environment for the development of rice cultivation. This relationship is consistent with the results of [56], which argue that in the case of unploughed soil, there is 
an increase in the carbon content in the surface layer, which improves the structural stability of the soil.

The cation exchange capacity of a soil represents the amount of cations (calcium, potassium, magnesium, sodium and ammonium) that it can retain on its clay-humic complex at a given $\mathrm{pH}$. It is also a measure of the number of negatively charged sites in the soil. The good cation exchange capacity (CEC) content of the soils studied is favourable for rice cultivation, as rice is better in soils with good nutrient retention capacities. Indeed, the CEC increases the availability of essential macro and micronutrients positively charged to adsorb on soil particles.

The average sodium content recorded in the soils studied is considered normal because, for reference purposes, the value of $0.5 \mathrm{Cmol} / \mathrm{kg}$ obtained is less than $0.7 \mathrm{Cmol} / \mathrm{kg}$ (threshold value). This indicates that soils present low risks of salinity for plants, and therefore favourable for agricultural soil. Since excess sodium could cause an aggravation of the beat, disruption of plant growth and an increase in soil $\mathrm{pH}$. In addition, the result of the exchangeable sodium content (ESP) $(8 \%)$ at the level of the soils studied is significantly lower than the threshold value (15\%). On the other hand, the soils in the irrigated area are of moderate salinity, which means that salinity at the M'Bahiakro area is unlikely to be an important limiting factor for rice cultivation. Generally, rice resists high doses of sea salt up to $7 \%$ sodium chloride $(\mathrm{NaCl})$ [57] because of the presence of a blade of water maintained almost permanently [58].

It should be noted that for this study, the reference standards for the different values of soil parameters were extracted from the reviews of some authors [59] [60] [61] [62].

\section{Conclusion}

This study assessed the physico-chemical quality of irrigation water and soils in the irrigated area of M'Bahiakro for sustainable rice production. The analysis of irrigation water shows good physico-chemistry and low to medium salinity according to the seasons of the year. As for the soils studied, they have a clayey-loam texture, a slightly acidic $\mathrm{pH}$, favourable to rice cultivation and a good organic matter content, which best maintains an active microbial life. In addition, the major elements (phosphorus and potassium) present in irrigation water and soil are sufficient for rice cultivation. On the other hand, the nitrogen levels obtained indicate a deficiency of this element in water and soil that can affect rice cultivation. Therefore, it would be important to note that, during the exploitation phase of the irrigated perimeter of M'Bahiakro through rice cultivation, a complementary supply of phosphorus and potassium (PK) fertilizer would not necessarily be necessary. However, it would be important that an adequate supplement of nitrogen $(\mathrm{N})$ fertilizer be provided to the soils of the irrigated area for a good yield from rice cultivation. In addition, for an appropriate diagnosis of irrigation water and soil quality, it would also be important to 
take into account the microbiological and heavy metals component, as water and soil pollution by heavy metals and microbes can pose a threat to sustainable rice production.

\section{Conflicts of Interest}

The authors declare no conflicts of interest regarding the publication of this paper.

\section{References}

[1] Fischer, G., Tubiello, N.F., Velthuizen, V.H. and Wiberg, A.D. (2007) Climate Change Impacts on Irrigation Water Requirements: Effects of Mitigation, 1990-2080. Technological Forecasting and Social Change, 74, 1083-1107. https://doi.org/10.1016/j.techfore.2006.05.021

[2] Yidana, M.S., Sakyi, A.P. and Stamp, G. (2011) Analysis of the Suitability of Surface Water for Irrigation Purposes: The Southwestern and Coastal River Systems in Ghana. Journal of Water Resource and Protection, 3, 695-710. https://doi.org/10.4236/jwarp.2011.310080

[3] Kebede, H., Fisher, K.D., Sui, R. and Reddy, N.K. (2014) Irrigation Methods and Scheduling in the Delta Region of Mississippi: Current Status and Strategies to Improve Irrigation Efficiency. American Journal of Plant Sciences, 5, 2917-2928. https://doi.org/10.4236/ajps.2014.520307

[4] Medici, M. and Wrachien, D.D. (2016) Challenges and Constraints in Irrigation and Drainage Development: A Worldwide View. Voice of the Publisher, 2, 9-12. https://doi.org/10.4236/vp.2016.22002

[5] ONDR-MINAGRI (2010) Stratégie de Développement Durable de la Riziculture en Côte d'Ivoire. Ministère de l'Agriculture, $10 \mathrm{p}$. http://www.riceforafrica.org/new/downloads/Meetings/gm4/GM4 G2 Pr\%C3\%A9s entation CIV \%20Fr.pdf

[6] Kouassi, K.L., Kouame, K.I., Konan, K.S., Dibi, B., Soumahoro, M., Kone, D. and Dago, G. (2013) Prospects for Minimizing the Potential Environmental Impacts of the Hydro-Agricultural Dam of M'Bahiakro (Côte d'Ivoire). Journal of Water Resource and Protection, 5, 847-853. https://doi.org/10.4236/jwarp.2013.59085

[7] Badraoui, M., Agbani, M. and Soudi, B. (2000) Evolution de la qualité des sols sous mise en valeur intensive au Maroc. Séminaire "Intensification agricole et qualité des sols et des eaux", Rabat, 2-3 Novembre 2000, $11 \mathrm{p}$.

[8] Ahoussi, K.E., Koffi, Y.B., Kouassi, A.M., Soro, G., Soro, N. and Biemi, J. (2012) Étude des caractéristiques chimiques et microbiologiques des ressources en eau du bassin versant du N'Zi: Cas de la commune de N'Zianouan (Sud de la Côte d'Ivoire). International Journal of Biological and Chemical Sciences, 6, 1854-1873. https://doi.org/10.4314/ijbcs.v6i4.40

[9] Ramaekers, H.R. (2001) Agriculture en Afrique tropicale DDCI, rues des petits cornes, 15, Karmelieteustrant 15, B 1000 Bruxelles. 611-636.

[10] Zhang, G.W. (1993) Effect of Temperature on Head Rice Rate. Chinese Journal of Rice Science, 7, 211-216.

[11] Meybeck, M. (1996) River Water Quality, Global Ranges, Time and Space Variabilities, Proposal for Some Redefinitions. Verhandlungen des Internationalen Verein Limnologie, 26, 81-96. https://doi.org/10.1080/03680770.1995.11900694 
[12] FAO (1999) Irrigation in Asia in Figures. FAO Water Report 18.

[13] Maynard, N.D. and Hochmuth, J.G. (1997) Knott's Handbook for Vegetable Growers. $582 \mathrm{p}$.

[14] Bornare, D., Nagarajan, R. and Barge, R. (2018) Improvement of Supplementary Irrigation Water Quality for Rain-Fed Agriculture in the Semi-Arid Region Using Magnetization Techniques. Journal of Water Resource and Protection, 10, 1198-1209. https://doi.org/10.4236/jwarp.2018.1012071

[15] Isabelle, C. (2006) Principaux critères pour évaluer la qualité de l'eau en micro-irrigation. Colloque sur l'irrigation l'eau, source de qualité et de rendement. CRAAQ (Centre de Référence en Agriculture et Agroalimentaire du Québec). 12 p.

[16] Dehedin, A., Piscart, C. and Marmonier, P. (2012) Seasonal Variations of the Effect of Temperature on Lethal and Sublethal Toxicities of Ammonia for Three Common Freshwater Shredders. Chemosphere, 90, 1016-1022.

https://doi.org/10.1016/j.chemosphere.2012.07.055

[17] Williams, K., Green, D. and Pascoe, D. (1986) Studies on the Acute Toxicity of Pollutants to Freshwater Macroinvertebrates. III: Ammonia. Archiv für Hydrobiologie, $106,61-70$.

[18] Allalgua, A., Kaouachi, N., Boualeg, C. and Ayari, A. (2017) Caractérisation Physico-chimique des eaux du barrage Foum El-Khanga (Région De Souk-Ahras, Algérie). European Scientific Journal, 13, 258. https://doi.org/10.19044/esj.2017.v13n12p258

[19] Ha, B., Zamini, L., Murungi, J.I., Muhoro, C.N., et al. (2017) Tropical Surface Water Quality Studies: Implications for the Aquatic Fate of N-Methyl Carbamate Pesticides. Journal of Environmental Science and Health, Part B, 53, 161-170. https://doi.org/10.1080/03601234.2017.1399768

[20] El Ghachtoul, Y., Alaoui, M.M. and Gabi, H. (2005) Eutrophisation des eaux des retenues des barrages Smir et Sehla (maroc): Causes, conséquences et consignes de gestion. Revue des sciences de P eau, 18, 75-89. https://doi.org/10.7202/705577ar

[21] Martin, J.M. (1980) Cycle des éléments chimiques dans les estuaires. Océanis, 5, 517-520.

[22] Hem, J.D. (1970) Study and Interpretation of the Chemical Characteristics of Natural Water US. Geological Survey, WSP 1473, Washington DC, 2nd Edition, 363.

[23] Antao, C., Bonner, H., Franco, J., Goyal, S., Iyer, D., Luengo, M., Pascual, J. and Shani, S. (2007) An Integrated Water, Sanitation and Health Strategy for the Municipality of Ruiru, Kenya. School of International and Public Affairs (SIPA), Columbia University, New York, 49 p.

[24] Ribbe, L., Delgado, P., Salgado, E. and Flugel, W. (2008) Nitrate Pollution of Surface Water Induced by Agricultural Non-Point Pollution in the Pocochay Watershed, Chile. Desalination, 226, 13-20. https://doi.org/10.1016/j.desal.2007.01.232

[25] Tiwari, T.N. and Manzoor, A. (1988) River Pollution in Kathmandu Valley (Nepal) Suitability of River Water for Irrigation. Indian Journal of Environmental Protection, 8, 269-274.

[26] Haritash, K.A., Kaushik, P.C., Kaushik, A., Kansal, A. and Yadav, K.A. (2008) Suitability Assessment of Groundwater for Drinking, Irrigation and Industrial Use in Some North Indian Villages. Environmental Monitoring and Assessment, 145, 397-406. https://doi.org/10.1007/s10661-007-0048-X

[27] Sundaray, S.K., Nayak, B.B. and Bhatta, D. (2009) Environmental Studies on River Water Quality with Reference to Suitability for Agricultural Purposes: Mahanadi 
River Estuarine System, India: A Case Study. Environmental Monitoring and Assessment, 155, 227-243. https://doi.org/10.1007/s10661-008-0431-2

[28] Islam, M.M., Azad, K.A., Ara, H.M., Rahman, M., Hassan, N., Swarnokar, C.S. and Rabeya, I. (2016) Environmental Study on a Coastal River of Bangladesh with Reference to Irrigation Water Quality Assessment: A Case Study on Shailmari River, Khulna. Journal of Geoscience and Environmental Protection, 4, 41-64. https://doi.org/10.4236/gep.2016.410003

[29] Orou, K.R., Soro, G., Soro, T.D., Traore, A., Fossou, N.R.M. and Soro, N. (2016) Aptitudes À L'agriculture Des Eaux Souterraines Du Département d'Agboville (Sud-Est de la Côte d'Ivoire). European Scientific Journal, 12, 81. https://doi.org/10.19044/esj.2016.v12n21p81

[30] Mengel, K. and Krikby, A.E. (1982) Principles of Plant Nutrition. Potash Inst. 3e ed. Worblanfen Ben Switzerland, $665 \mathrm{p}$.

[31] Kundu, R. and Ara, M.H. (2019) Irrigation Water Quality Assessment of Chitra River, Southwest Bangladesh. Journal of Géoscience and Environment Protection, 7, 175-191. https://doi.org/10.4236/gep.2019.74011

[32] Walter, P.K. (1963) Use of Saline Irrigation Water. Soil Science, 95, 385-391. https://doi.org/10.1097/00010694-196306000-00003

[33] Paliwal, K.V. and Singh, S. (1967) Effect of Gypsum Application on the Quality of Irrigation Waters. Madras Agricultural Journal, 59, 646-647.

[34] Wilcox, L.V. (1948) The Quality of Water for Agricultural Use. US Department of Agriculture, Technical Bulletin, Vol. 962, Washington DC, 40 p.

[35] Banton, O. and Bangoy, M.L. (1997) Hydrogéologie: Multi-Science Environnementale des eaux souterraines. Université du Québec, Québec, 460 p.

[36] Bationo, B.A. (1994) Gestion de la fertilité des sols. FAO: Cours de formation: Le Travail du Sol pour une Agriculture Durable (Chapitre 11), 4-13 juillet 1994, Niamey (Niger). http://www.fao.org/docrep/W7304F/w7304f0b.htm

[37] Zingore, S., Wairegi, L. and N’Diaye, K.M. (2014) Guide pour la gestion des systèmes de culture de riz. Consortium Africain pour la Santé des Sols, Nairobi. Le Consortium Africain pour la Santé des Sols (ASHC), 60.

[38] Memento de l'agronome (1993) Référence d'interprétation pour un sol Tropical. $1698 \mathrm{p}$.

[39] Beaudin, I., Michaud, A., Beaudet, P. and Giroux, M. (2008) La mobilité du phosphore: Du sol au cours d'eau. Fiche technique $\mathrm{n}^{\circ} 1$. Centre de référence en agriculture et agroalimentaire du Québec, Quebec, 8 p.

[40] Dumont, R. (2017) La culture du riz dans le delta du tonkin. Éditions de la Maison des sciences de l'homme. Science sociale/Agriculture et nourriture. 145-191.

[41] Beaudin, I. (2006) Revue littéraire la mobilité du phosphore: Version finale. Centre de référence en agriculture et agroalimentaire du Québec, Québec, 137 p.

[42] Mhiri, A. (2002) Le potassium dans les sols de Tunisie, Atelier sur la gestion de la fertilité potassique, acquis et perspectives de la recherche. Institut National Agronomique de Tunisie, $13 \mathrm{p}$.

[43] Krauss, A. (1997) Potassium, le nutriment oublié en Asie occidentale et en Afrique du Nord: Réalisations et défis futurs dans la recherche sur la fertilité des sols et des terres arides dans la région méditerranéenne. ICARDA, Syrie, 9-21.

[44] Bosc, J.M. (1988) Enseignements fournis par des essais de longue durée sur la fumure phosphatée et potassique. 3 essais sur la fumure potassique. In: Gachon, D., Ed., Phosphore et potassium dans les relations sol-plante. Conséquences sur la 
fertilisation, INRA, Paris, 409-466.

[45] Boniface, R. and Trocme, S. (1988) Enseignements fournis par des essais de longue durée sur la fumure phosphatée et potassique. 2 essais sur la fumure phosphatée. In: Gachon, Ed., Phosphore et potassium dans les relations sol-plante. Conséquence sur la fertilisation, INRA, Paris, 279-402.

[46] Kambire, S.H. (1994) Systèmes de culture paysan et productivité des sols ferrugineux lessivés du plateau central (Burkina Faso): Effets des restitutions organiques. Thèse de doctorat troisième cycle, université de Dakar, Dakar, $188 \mathrm{p}$.

[47] Kawano, K. (2000) The Role of Improved Cassava Cultivars in Generating Income for Better Farm Management. Proceedings of 6 th Regional Workshop, Ho Chi Minh City, 5-15.

[48] Nye, P.H. (1958) The Relative Importance of Fallows and Soils in Storing Nutrients in Ghana. Journal of West Africa Science Association, 4, 31-49.

[49] Blondel, D. (1971) Contribution à l'étude de la dynamique de l'azote en sol sableux (dior) au Sénégal. L'Agronomie Tropicale, 26, 1303-1333.

[50] Rosswall, T. (1980) Nitrogen Cycling in West African Ecosystems. SCOPE/UNEP International Nitrogen Unit, Stockholm, 450.

[51] Wopereis, C.S.M., Defoer, T., Idinoba, P., Diack, S. and Dugué, M. (2008) Curriculum d'apprentissage participatif et recherche action (APRA) pour la gestion intégrée de la culture de riz de bas-fonds (GIR) en Afrique subsaharienne: Manuel technique. Le Centre du riz pour l'Afrique (ADRAO), Cotonou, Vol. 6, $128 \mathrm{p}$

[52] Fageria, N.K. and Baligar, V.C. (2001) Lowland Rice Respond to Nitrogen Fertilisation. Communications in Soil Science and Plant Analysis, 32, 1405-1429. https://doi.org/10.1081/CSS-100104202

[53] Huber, G. and Schaub, C. (2011) La fertilité des sols: L'importance de la matière organique. Chambre d'Agriculture, Bas-Rhin. Service Environnement-Innovation, $46 \mathrm{p}$.

[54] Ballot, A.C., Mawussi, G., Atakpama, W., Moita, N.M., Yangakola, T.M., Zinga, I., Semballa, S., Kperkouma, W., Dercon, G., Komlan, B. and Koffi, A. (2016) Caractérisation physico-chimique des sols en vue de l'amélioration de la productivité du manioc (Manihot esculenta Crantz) dans la région de Damara au centre-sud de Centrafrique. Agronomie Africaine, 28, 9-23.

[55] Bationo, B.A. and Buerkert, A. (2001) Soil Organic Carbon Management for Sustainable Land Use in Sudano-Sahelian West Africa. Nutrient Cycling in Agroecosystems, 61, 131-142. https://doi.org/10.1007/978-94-017-2172-1 13

[56] Angers, A.D., Samson, N. and Legere, A. (1993) Early Changes in Water-Stable Aggregation Induced by Rotation and Tillage in a Soil under Barley Production. Canadian Journal of Soil Science, 73, 51-59. https://doi.org/10.4141/cjss93-005

[57] Poussin, J.C., Boivin, P., Hammeck, C. and Maeght, J.L. (2002) Riziculture irriguée et évolution des sols dans la vallée du Sénégal, acte de l'atelier du PCSI, CIRAD, IRD. 8 p. http://hal.cirad.fr/cirad-00179330

[58] Schiess, S., Boivin, P., Pury, D.P. and Vedy, J.C. (1995) Alcalinisation des sols irrigués dans la moyenne vallée du fleuve Sénégal: Diagnostique par évaluation du stock de carbonates. Travail pratique de diplôme, EPFL (École Polytechnique Fédérale de Lausanne) Département de Génie Rural IATE-Pédologie. 52 p.

[59] Landon, J.R. (1991) Booker Tropical Soil Manual: A Handbook for Soil Survey and Agricultural Land Evaluation in the Tropics and Subtropics. Booker Tate Limited, Oxon, Longman Scientific \& Technical, Harlow, 474 p.

[60] CRAAQ (2003) Guide de référence en fertilisation. Centre de référence en 
agriculture et agroalimentaire du Québec, Sainte-Foy, Vol. 20, 294 p.

[61] Giroux, M. and Audesse, P. (2004) Comparaison de deux méthodes de détermination des teneurs en carbone organique, en azote total et $\mathrm{du}$ rapport $\mathrm{C} / \mathrm{N}$ de divers amendements organiques et engrais de ferme. Agrosol, 15, 107-110.

[62] Doucet, R. (2006) Le climat et les sols agricoles. Edition, Berger, Eastman, Québec. Vol. 15, 443 p. 